\title{
Negative Aspects of the Use of Infocommunication Technologies by Undergraduate Students of Engineering Academic Programs in a Regional Russian University
}

\author{
Vsevolod V. Andreev1,*, Vladimir I. Gorbunov², Olga K. Evdokimova³, Irina G. Nikitina4, \\ Iraida G. Trofimova ${ }^{4}$ \\ ${ }^{1}$ Department of Heat Power Setups, Faculty of Energy and Electrical Engineering, Chuvash State University, Russia \\ ${ }^{2}$ Department of Automation and Control in Technical Systems, Faculty of Radio Electronics and Automation, \\ Chuvash State University, Russia \\ ${ }^{3}$ Department of Russian Language and Literature, Faculty of Russian and Chuvash Philology and Journalism, \\ Chuvash State University, Russia \\ ${ }^{4}$ Department of Foreign Languages, Faculty of Foreign Languages, Chuvash State University, Cheboksary, Russia
}

Received November 22, 2019; Revised January 27, 2020; Accepted February 7, 2020

Copyright $\odot 2020$ by authors, all rights reserved. Authors agree that this article remains permanently open access under the terms of the Creative Commons Attribution License 4.0 International License

\begin{abstract}
A test containing 12 questions and a questionnaire comprising 15 pairs of statements have been developed. 171 undergraduate students have been tested and surveyed. A statistical processing of the results has been carried out, and charts illustrating the survey results have been built. When analyzing the data, summarizing the results and formulating conclusions, a systematic approach was applied. There are six types of Internet activities that are most characteristic of the student body in question. With the help of the questionnaire based on a pair-wise comparison method, the relative time spent by the respondents on these activities was determined. The students were proved to spend approximately as much time on their studies as they do on each of the following three activities: communication with friends, hobbies and aimless surfing the network. The students are less interested in playing games or watching news. One cannot deny the benefits of using ICT for pursuing hobbies, but it is obvious the amount of time wasted on browsing the network should be reduced. Besides, it is significant to replace virtual communication with friends by their face-to-face interaction at least partially. The language of social networks is far from observing literary norms. It ignores rules of punctuation and spelling. Taken out from virtual space into real life, this youth's slang affects their behavior, way of thinking, which is, in fact, destructive for their personalities. Students' overuse of ICT is a major social problem resulting in the decline in the quality of their education. In our opinion, for engineering students the reasons for this problem lies in their insufficient level
\end{abstract}

of general culture, lack of self-discipline and strong willpower, underestimated need for knowledge, and lack of a meaningful, profession-oriented goal of education.

Keywords Infocommunication Technologies, Educational Process, Internet Addiction, Questionnaire, Testing, Statistical Processing of the Results, System Approach, Negative Aspects of ICT in Education

\section{Introduction}

The key elements of the innovations caused by the transition to new state educational standards in Russia are individualization of instruction due to a higher proportion of elective courses and the use of learning credits; the growing role of self study for students, their research work and its proper supervision. Furthermore, "transparency" of the educational process through detailed methodological support for subjects and its openness; point-rating evaluation of the results achieved in learning activities, a wide application of information and computer technologies are of great importance as well.

The volume of the undergraduate program is 240 learning credits ( 1 credit is 36 academic hours), the course of study lasting 4 years. The university is entitled to use e-learning and distance educational technologies. The online form can be used. System-wide requirements for the implementation of undergraduate programs include unlimited access to electronic library systems and to the 
electronic information and educational environment of the organization. In particular, the latter is to provide teaching using e-learning, distance educational technologies, synchronous and (or) asynchronous interaction between participants of the educational process via the Internet.

ICT include all devices and technologies that provide access to information network resources and all necessary actions with information and data in networks (for example, in the Internet). Therefore, the concepts of "Internet" and "ICT" are inextricably linked and do not exist without each other. This comment is for those (including reviewers) who are trying to consider them in isolation from each other.

One of the most important purposes of infocommunication technologies (ICT) using in the educational process is that, they provide a quick search for information required, resources for its transformation, and contribute to the formation of independence and creative activity of students. However, it often happens that ICT, as well as the time spent on infocommunication networks are often used inefficiently. One important reason is that the freedom of choice can degenerate that into lack of control, permissiveness. ICT are turning into an object of psychological dependence and, thus negatively affects the process and dynamics of forming a future specialist at a university. This research aims to identify the degree of inefficient use of ICT by engineering baccalaureate students, and carry out system analysis of its reasons.

The relevance of the study is due to the fact that often by obtaining information, i.e. initial stage of learning, the process of cognition with the help of ICT comes to the end: the student does not even think about the implementation of the main educational action - turning information into knowledge through cognitive and creative activities as he is often distracted by other "options" provided by ICT: communication, entertainment, etc. Consequently, enabled independence and freedom of choice grow into absence of control and permissiveness. As a result, students waste their time, and the Internet, social networks become an object of psychological dependence, negatively affecting the process and dynamics of the formation of the future specialist. To facilitate solution to the problem it is important to form a system of motivational, emotional-volitional and value-semantic personal features that increases the psychological resistance of a person to the negative impact of ICT and Internet technologies can help. Significant differences between Internet-addicted people and those who are not addicted can be found in the indicators of their personal self-esteem. One can assume that people with a high level of ICT and Internet addiction are unable adequately to assess their abilities, which is revealed in a low level of their self-esteem.

One of the most acute problems of integrating ICT into everyday life is its negative impact on students. Special attention should be paid to the fact that ICT negatively affects not only students' academic performance, but, mainly, their mentality, health and socialization. We believe that the study of the negative impact of ICT on university students is very important and ought to be continued.

The aim of the research is to identify the degree of inefficient use of ICT by engineering undergraduate students and carry out system analysis of this phenomenon.

\section{Literature Review}

Modern educational process is unthinkable without the use of ICT. They provide a quick search for the right information and resources for its conversion. Thanks to its interactive mode of operation and the specifics in the activity, the student's motivation significantly increases, socially approved personality traits are brought up, including perseverance in achieving the goal and even modesty, since self-confidence, reduced self-criticism are quickly punished. All this can contribute to the formation of students' independence and their creative abilities, the qualities required for a modern specialist who has been trained at the university (Gorbunov et al. 2016). In particular, the key role of ICT in the educational process is shown by Rajabion et al. (2019).

The main distinguishing feature of modern university students is their close relationship with ICT. However, the results of some studies (for example, Florjančič 2015) testify that first-year students have no appropriate skills in the targeted application of ICT in the educational process. List (2019) analyzed various aspects of student digital literacy development. A bibliometric analysis of scientific researches published during the period from 2006 to 2017 devoted to the study of literacy in the application of mobile information technologies in higher education was made by Pinto et al. (2019). The researches to determine the relationship between socio-economic status indicators (SES) and ICT literacy among students are highly controversial (Hatlevik and Christophersen 2013; Hohlfeld et al. 2013; Scherer and Siddiq 2019). So, Scherer and Siddiq (2019) found a positive correlation between the level of student literacy in the field of ICT and SES. However, the relation between SES and ICT literacy is weaker than that in other educational areas, such as mathematics and reading. Rizvi et al. (2019) in their study found a close relationship between online student academic performance and demographic characteristics, such as regional affiliation, socio-economic status, level of education, age, gender, and disability status. The study of gender differences in student academic performance in the field of ICT is the research theme for Siddiq and Scherer (2019).

Based on the analysis of student survey results at Latvia University of Life Sciences and Technologies, Zeidmane (2019) concluded that about $63 \%$ of the time spent on the Internet is used by students for non-academic purposes. Internet addiction can significantly transform a student's 
individuality (Young and Brand 2017) and affect the results of his professional training as a future specialist. The negative impact of ICT is manifested in the deviant behavior of students, and has a detrimental effect on the quality of professional training of future specialists, their psychological and physical health and, probably, most importantly on their socialization. To overcome such consequences at the theoretical and methodological level, the ways to reduce a negative impact of ICT and Internet technologies on students are substantiated.

Thus, higher education institutions face significant challenges in finding ways to improve the educational process and student academic performance in the era of active introduction of ICT into everyday life. The problems that traditional universities encounter in the process of introducing ICT into the educational process have been studied by Florjančič (2019). Alemu (2015) explored the prospects, problems and future directions of higher education institutions in view of wide integration of ICT into teaching and learning practices. The effectiveness of ICT use in higher education in terms of sustainable development in the future was studied by Suryawanshi (2019). Giannakopoulos and Eybers (2015); Luisa Sevillano-Garcia and Vazquez-Canon (2015) explored the prospects of introducing mobile technologies to improve teaching and learning. Al-arabi et al. (2019) studied the technological aspect of readiness for e-learning in higher education. They proposed a model that includes eight technological factors that have a significant impact on e-learning readiness: software, hardware, connectivity, security, system flexibility, technical skills and support, cloud computing and a Data center. Education Management Information Systems (EMIS), which provide educational institutions and students with the opportunity to use high-quality and structured information, have been studied by Martins et al. (2019). Hernandez-de-Menendez and Morales-Menendez (2019) examined the current state of ICT, which can be applied in the field of engineering education, and generalized innovative technological tools, trends and teaching methods for successful education.

The method of teaching "the flipped classroom approach" (Abeysekera and Dawson 2015; Cruzado and Román 2015; O'Flaherty and Phillips 2015; Goedhart et al. 2019) is being used more and more actively in universities. The main idea of the method is to give information to students before class in the form of instructional videos, recorded lectures and other remotely accessible pedagogical resources. As a result, the task of the teacher in the classroom is shifted to a deeper conceptual coverage of the topic being studied through the active involvement of students into comprehensive problem solving in the classroom. The Flipped Classroom educational strategy improves students and teachers' interaction. ICT, online learning tools and cloud services provide a flexible way to integrate Flipped Classroom technology into engineering universities. Priyaadharshini and Vinayaga Sundaram (2017) conducted an analysis of the Flipped Classroom impact on lifelong learning based on student behavioral models such as cognitive, conative and affective ones. Prevalla and Uzunboylu (2019), through a critical assessment of researches and generalizing thier results, reviewed the current state of knowledge and practice of applying Flipped Learning in engineering education.

Tokareva et al. (2019) examined the students' point of view of the quality of ICT application in the educational process. Based on the analysis of student survey results, the researchers analyzed the following aspects of the problem: students' views of education program innovativeness, teachers' participation in the ICT introduction and technological support from the management in applying ICT in various universities. Based on the adoption model of e-learning tools (eLTAM), Valencia-Arias et al. (2019) examined the adoption rate and critical factors of virtual learning among university students in developing countries. Fernandez Batanero et al. (2019) noted in their research that the field of ICT as a means of supporting the education of gifted students is not sufficiently studied. There is also an urgent need to improve teacher training curricula in order to enhance their digital competencies.

Main aspects of interaction and cooperation within the framework of the knowledge triangle (KT), which includes business, higher education and research as a determining factor in the innovative development of European countries are analyzed by Smol, Kulczycka (2019). The ways of effective joint use of information technologies and STEM-education based on the idea of education using interdisciplinary and applied approaches, have been studied by Hollman et al. (2019). It should be noted that inter- and transdisciplinary approaches as an effective means of enhancing students' cognitive and educational activities are considered in many studies (Andreev et al. 2017; Gorbunov et al. 2019; Barrera et al. 2018; Tejedor et al. 2018).

\section{Research Method}

Materials and methods are conditioned by the purpose of this study, related to determining the degree of inefficient use of ICT by undergraduate students of engineering academic programs.

To identify negative aspects of the use of ICT and Internet technologies by engineering undergraduate students, we use K. Young's test as a basis for determining Internet-addiction (Young 1998). Since no identification of Internet-addiction has been made in the present study, we found it reasonable to modify this test by adding our questions, each question having options for intermediate answers, apart from traditional "yes" and "no" (Table 1). 
Table 1. Students' survey questions and answer options

\begin{tabular}{|l|l|}
\hline Questions & Answer option \\
\hline $\begin{array}{l}\text { 1. Do you use the Internet to avoid problems, get rid of a bad mood, and relieve } \\
\text { stress? }\end{array}$ & Yes, no, not always \\
\hline 2. Are you able to manage your time on the Internet? & Yes, no, not always \\
\hline 3. Do you spend more time online than you planned? & Yes, no, occasionally \\
\hline $\begin{array}{l}\text { 4. Do you conceal from your family members and friends what you spend your time } \\
\text { online on? }\end{array}$ & Yes, no, occasionally \\
\hline 5. Do you feel anxious or annoyed when you are taken away from the Internet? & Yes, no, occasionally \\
\hline 6. Do you look forward to your surfing the Internet? & Yes, no, occasionally \\
\hline 7. Do you feel not at ease being offline? & Yes, no, occasionally \\
\hline 8. Do your studies or relationship with people suffer because of your Internet use? & Yes, no, occasionally \\
\hline 9. Do people around you draw your attention to your excessive use of the Internet? & Yes, no, occasionally \\
\hline 10. Do you sacrifice your health, hygiene, sleep for ICT? & Yes, no, occasionally \\
\hline 11. How many hours do you spend on the Internet on average daily? & $1,2,3,4,5,6,7,8$ hours or more \\
\hline 12. What time do you usually spend online? & $\begin{array}{l}\text { Afternoon, early evening, until } 12 \text { p.m., after } 12 \\
\text { p.m. }\end{array}$ \\
\hline
\end{tabular}

Table 2. Questionnaire

The survey is anonymous. It is important to respond truthfully and honestly. You are presented with several types of possible online activities. They are grouped in pairs (in two types) in different combinations. In each pair you are to choose (mark with any symbol) only one type of activity, the one you spend most of your time online.

\begin{tabular}{|c|c|}
\hline Online activities grouped in pairs & Answer \\
\hline $\begin{array}{l}\text { 1. Education issues (searching for necessary information, communicating with group-mates). } \\
\text { 2. Random browsing. }\end{array}$ & \\
\hline $\begin{array}{l}\text { 1. Education issues (searching for necessary information, communicating with group-mates). } \\
\text { 3. Communicating with friends, mates with the same interests. }\end{array}$ & \\
\hline $\begin{array}{l}\text { 1. Education issues (searching for necessary information, communicating with group-mates). } \\
\text { 4. Your favourite pastimes, hobbies: music, painting, movies, museums, fashion, shopping, etc. (except for games). }\end{array}$ & \\
\hline $\begin{array}{l}\text { 1. Education issues (searching for necessary information, communicating with group-mates). } \\
\text { 5. Playing games. }\end{array}$ & \\
\hline $\begin{array}{l}\text { 1. Education issues (searching for necessary information, communicating with group-mates). } \\
\text { 6. News (politics, sport, the arts, science, secrets of the universe, etc.). }\end{array}$ & \\
\hline $\begin{array}{l}\text { 2. Random browsing. } \\
\text { 3. Communicating with friends, mates with the same interests. }\end{array}$ & \\
\hline $\begin{array}{l}\text { 2. Random browsing (without a plan, a specific purpose). } \\
\text { 4. Your favourite pastimes, hobbies: music, painting, movies, museums, fashion, shopping, etc. (except for games). }\end{array}$ & \\
\hline $\begin{array}{l}\text { 2. Random browsing. } \\
\text { 5. Playing games. }\end{array}$ & \\
\hline $\begin{array}{l}\text { 2. Random browsing. } \\
\text { 6. News (politics, sports, art, science, secrets of the universe, etc.). }\end{array}$ & \\
\hline $\begin{array}{l}\text { 3. Communicating with friends, mates with the same interests. } \\
\text { 4. Your favourite pastimes, hobbies: music, painting, movies, museums, fashion, shopping, etc. (except for games). }\end{array}$ & \\
\hline $\begin{array}{l}\text { 3. Communicating with friends, mates with the same interests. } \\
\text { 5. Playing games. }\end{array}$ & \\
\hline $\begin{array}{l}\text { 3. Communicating with friends, mates with the same interests. } \\
\text { 6. News (politics, sport, the arts, science, secrets of the universe, etc.). }\end{array}$ & \\
\hline $\begin{array}{l}\text { 4. Your favourite pastimes, hobbies: music, painting, movies, museums, fashion, shopping, etc. (except for games). } \\
\text { 5. Playing games. }\end{array}$ & \\
\hline $\begin{array}{l}\text { 4. Your favourite pastimes, hobbies: music, painting, movies, museums, fashion, shopping, etc. (except for games). } \\
\text { 6. News (politics, sport, the arts, science, secrets of the universe, etc.). }\end{array}$ & \\
\hline $\begin{array}{l}\text { 5. Playing games. } \\
\text { 6. News (politics, sport, the arts, science, secrets of the universe, etc.). }\end{array}$ & \\
\hline
\end{tabular}


In addition to this test (Table 1), a questionnaire developed by the authors was used (Table 2), with its help relative time spent by respondents on the following six types of online activities was measured.

1. Activities related to the solution of educational issues (searching for the necessary information, online communicating with fellow students, a curator, teachers, dean's office).

2. Haphazard surfing the network, viewing information about everything (without a specific plan), aimless pastime.

3. Communicating with friends, mates with the same interests.

4. Activities related to favourite pastimes, hobbies: music, painting, literature, films, fashion, shopping, museums, the basics of the universe, etc. (except games).

5. Playing games.

6. Watching news in the field of the arts, politics, sport, science, etc.

Our preliminary survey experience on this topic shows that when asking straightforward, non-alternative questions (for example, "Number the proposed activities on the network in the order of importance for you"), some students give the answers in a way to make a better impression.

In this regard, to reduce the distorting effect of subjective and random factors, activities are grouped in pairs in the questionnaire (for six activities, 15 pairs are possible). In each pair, the respondent is to choose one dominant type. Since each activity is mentioned in the questionnaire 5 times, its ranking can have a value from 0 to 5 . With equal attention to each of the six activities, the average rank would amount to 2.5. This technique of pair-wise comparison does not oblige the respondents to give their answers in an integer format but enables to move from the ranking assessment to a more precise interval scale.

Test questions and questionnaires were posted on the Google Forms online service, designed to create feedback forms, online testing and surveys. The survey received responses from 171 students of the Chuvash State University: 137 students of the Faculty of Radio Electronics and Automation (1- 4 years) and 34 first-year philology students, including 10 foreign students. Philology students were taken as a kind of a control (comparison) group. We also note that engineering baccalaureate students are mainly young men, whereas most philology students are girls.

A theoretical analysis of scientific sources, questionnaire survey, testing, statistical processing of the results have been conducted. The information received has been tabulated. Charts illustrating the students' answers to the test questions are built. When analyzing the data, summarizing the results and formulating conclusions, a system approach was applied, which allows us to consider the material discussed in the study in the form of a single complex of interrelated elements.

\section{Results and Discussion}

The test results for the first 10 questions (see Table 1) (the number of students who gave answers) are presented in Table 3.

One can see a similar distribution pattern for answers to most questions among the respondents of all courses. For example, question 2 has a minimum frequency of "No", a small proportion of intermediate answers, and a prevailing number of "Yes" answers (Fig. 1). 
Table 3. Initial test results.

\begin{tabular}{|c|c|c|c|c|c|c|c|}
\hline \multirow[b]{2}{*}{$\begin{array}{l}\text { Question } \\
\text { numbers }\end{array}$} & \multirow[b]{2}{*}{$\begin{array}{l}\text { Answer } \\
\text { option }\end{array}$} & \multicolumn{4}{|c|}{ Engineering students } & \multicolumn{2}{|c|}{ Students-philologists } \\
\hline & & $\begin{array}{c}1 \text { year } \\
(42 \\
\text { students })\end{array}$ & $\begin{array}{c}2 \text { year } \\
(30 \\
\text { students })\end{array}$ & $\begin{array}{c}3 \text { year } \\
(36 \\
\text { students })\end{array}$ & $\begin{array}{c}4 \text { year } \\
(29 \\
\text { students) }\end{array}$ & $\begin{array}{c}1 \text { year } \\
24 \\
\text { students) }\end{array}$ & $\begin{array}{c}1 \text { year } \\
\text { (10 foreign } \\
\text { students) }\end{array}$ \\
\hline \multirow{3}{*}{1} & Yes & 11 & 9 & 17 & 6 & 14 & 3 \\
\hline & Not always & 13 & 12 & 13 & 15 & 7 & 5 \\
\hline & No & 8 & 9 & 6 & 8 & 3 & 2 \\
\hline \multirow{3}{*}{2} & Yes & 33 & 26 & 30 & 20 & 13 & 7 \\
\hline & Not always & 8 & 4 & 5 & 8 & 9 & 2 \\
\hline & No & 1 & 0 & 1 & 1 & 2 & 1 \\
\hline \multirow{3}{*}{3} & Yes & 5 & 4 & 5 & 8 & 9 & 1 \\
\hline & Occasionally & 18 & 12 & 20 & 10 & 8 & 4 \\
\hline & No & 19 & 14 & 11 & 11 & 7 & 5 \\
\hline \multirow{3}{*}{4} & Yes & 3 & 2 & 4 & 2 & 5 & 1 \\
\hline & Occasionally & 1 & 2 & 2 & 8 & 8 & 0 \\
\hline & No & 38 & 26 & 30 & 19 & 11 & 9 \\
\hline \multirow{3}{*}{5} & Yes & 2 & 0 & 2 & 2 & 1 & 1 \\
\hline & Occasionally & 5 & 5 & 3 & 5 & 10 & 2 \\
\hline & No & 35 & 25 & 31 & 22 & 13 & 7 \\
\hline \multirow{3}{*}{6} & Yes & 3 & 0 & 2 & 2 & 3 & 1 \\
\hline & Occasionally & 8 & 7 & 6 & 5 & 8 & 1 \\
\hline & No & 31 & 23 & 28 & 22 & 13 & 8 \\
\hline \multirow{3}{*}{7} & Yes & 0 & 0 & 0 & 0 & 2 & 1 \\
\hline & Occasionally & 5 & 2 & 3 & 4 & 4 & 1 \\
\hline & No & 37 & 28 & 33 & 25 & 18 & 8 \\
\hline \multirow{3}{*}{8} & Yes & 1 & 3 & 0 & 0 & 2 & 2 \\
\hline & Occasionally & 1 & 4 & 6 & 8 & 5 & 0 \\
\hline & No & 40 & 23 & 30 & 21 & 17 & 8 \\
\hline \multirow{3}{*}{9} & Yes & 2 & 5 & 3 & 2 & 4 & 2 \\
\hline & Occasionally & 8 & 5 & 6 & 9 & 5 & 1 \\
\hline & No & 32 & 20 & 27 & 18 & 15 & 7 \\
\hline \multirow{3}{*}{10} & Yes & 6 & 3 & 0 & 2 & 4 & 1 \\
\hline & Occasionally & 0 & 2 & 4 & 7 & 4 & 0 \\
\hline & No & 36 & 25 & 32 & 20 & 16 & 9 \\
\hline
\end{tabular}


by Undergraduate Students of Engineering Academic Programs in a Regional Russian University

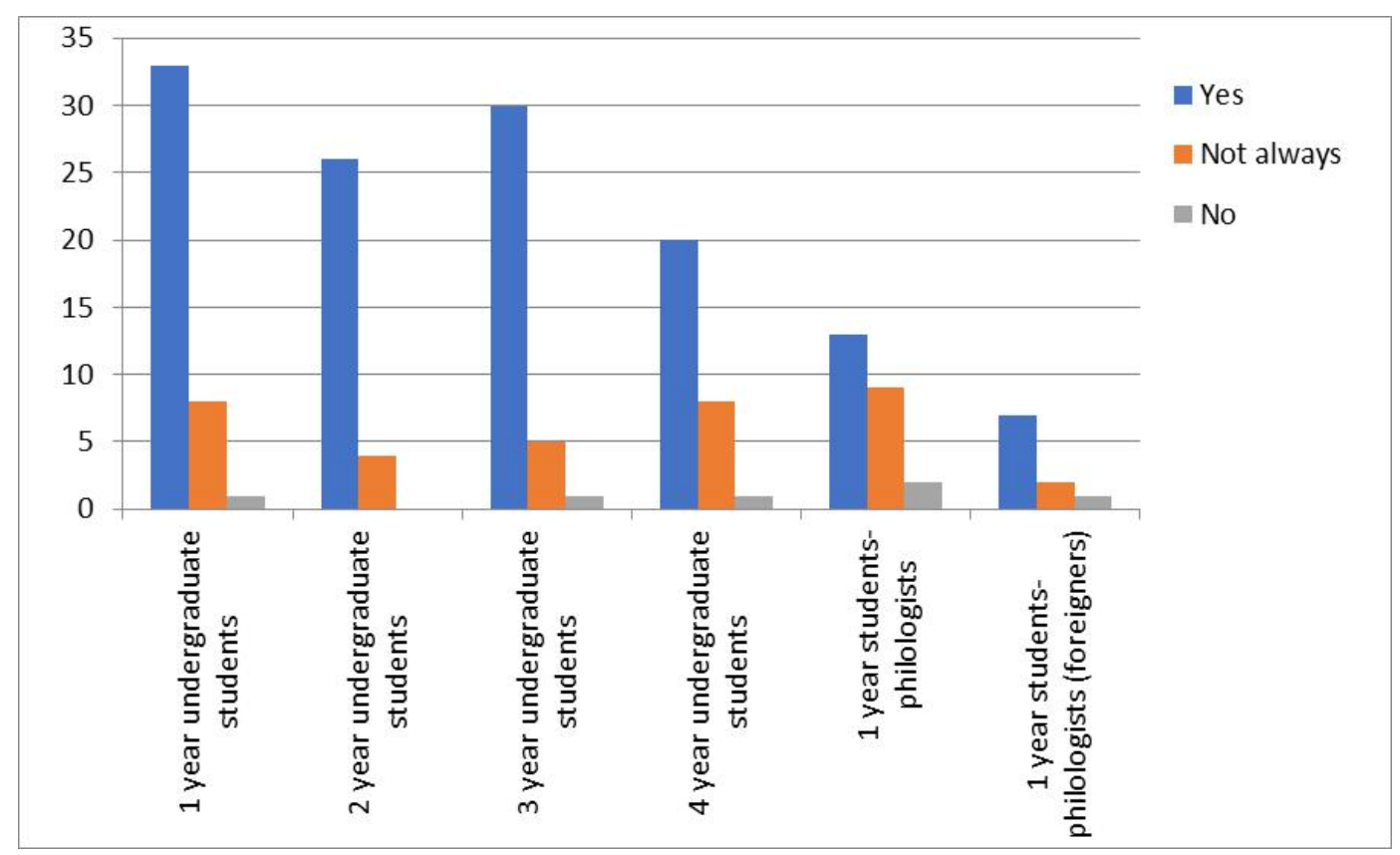

Figure 1. Distribution by study years of respondents' answers to test question 2: “Are you able to manage your time on the Internet?" The students number is indicated on the vertical axis

Table 4. The generalized test results for the first 10 questions.

\begin{tabular}{|c|c|c|c|}
\hline Question numbers & Answer option & All engineering undergraduate students (137 students) & $\begin{array}{l}\text { Students-philologists } \\
\text { (34 students) }\end{array}$ \\
\hline \multirow{3}{*}{1} & Yes & $31 \%$ & $50 \%$ \\
\hline & Not always & $39 \%$ & $35 \%$ \\
\hline & No & $30 \%$ & $15 \%$ \\
\hline \multirow{3}{*}{2} & Yes & $80 \%$ & $59 \%$ \\
\hline & Not always & $18 \%$ & $32 \%$ \\
\hline & No & $2 \%$ & $9 \%$ \\
\hline \multirow{3}{*}{3} & Yes & $16 \%$ & $30 \%$ \\
\hline & Occasionally & $44 \%$ & $35 \%$ \\
\hline & No & $40 \%$ & $35 \%$ \\
\hline \multirow{3}{*}{4} & Yes & $8 \%$ & $18 \%$ \\
\hline & Occasionally & $10 \%$ & $23 \%$ \\
\hline & No & $82 \%$ & $59 \%$ \\
\hline \multirow{3}{*}{5} & Yes & $4 \%$ & $6 \%$ \\
\hline & Occasionally & $28 \%$ & $35 \%$ \\
\hline & No & $68 \%$ & $59 \%$ \\
\hline \multirow{3}{*}{6} & Yes & $5 \%$ & $12 \%$ \\
\hline & Occasionally & $26 \%$ & $26 \%$ \\
\hline & No & $69 \%$ & $62 \%$ \\
\hline \multirow{3}{*}{7} & Yes & $0 \%$ & $9 \%$ \\
\hline & Occasionally & $10 \%$ & $15 \%$ \\
\hline & No & $90 \%$ & $76 \%$ \\
\hline \multirow{3}{*}{8} & Yes & $3 \%$ & $11 \%$ \\
\hline & Occasionally & $14 \%$ & $15 \%$ \\
\hline & No & $83 \%$ & $74 \%$ \\
\hline \multirow{3}{*}{9} & Yes & $9 \%$ & $18 \%$ \\
\hline & Occasionally & $20 \%$ & $18 \%$ \\
\hline & No & $71 \%$ & $64 \%$ \\
\hline \multirow{3}{*}{10} & Yes & $8 \%$ & $15 \%$ \\
\hline & Occasionally & $10 \%$ & $11 \%$ \\
\hline & No & $82 \%$ & $74 \%$ \\
\hline
\end{tabular}


Taking into account the identical nature of the distribution of options for answers among all the respondents, for greater clarity we find it appropriate to categorize engineering students and students of the faculty of philology into different groups. The generalized test results for the first 10 questions in these two categories of respondents are presented in Table 4.

The answers to question 1 show that many respondents use the Internet to avoid problems, to get rid of a bad mood. $31 \%$ of the engineering students state it firmly, $39 \%$ say "Not always". In comparison with the students-philologists the percentage is $50 \%$ and $35 \%$ respectively (Fig.2). Apparently, one of the reasons for this can be gender differences.

Question 2 seems uninformative. Most engineering students $(80 \%)$ manage their time online, whereas it is less characteristic of the students-philologists, apparently, due to the difference in their specialities. In particular, more developed logical thinking of engineering students may be the reason for the disparity.

According to the responses to question 3,16\% of the engineering students spend more time surfing the Internet than they planned, and for $44 \%$ of the engineering students it occurs occasionally (for the students-philologists these figures are $30 \%$ and $35 \%$ respectively).

The answers to question 4 show greater openness of the male students compared to the female students.

Answers to question 5 reveal more steadiness of character of engineering students (to a lesser extent, this is typical of future philologists). The answers to question 6 concerning their expectancy of next surfing the Internet were similar: mostly - "No", only $26 \%$ - "Occasionally".

Question 7 could have been excluded from the test: $90 \%$ of the students answered "No".

Few respondents believe the Internet affects their studies or relationship with people to some degree: $17 \%$ of engineering students and $26 \%$ of students-philologists (question 8).

Approximately one third of respondents in both categories admitted that they are told of excessive surfing the Internet (question 9). $18 \%$ of the young men, $26 \%$ of the girls have to sacrifice their health, hygiene, sleep for ICT (question 10).

The answers to questions 11 and 12 of the test (see Table 1) are presented in Table 5.

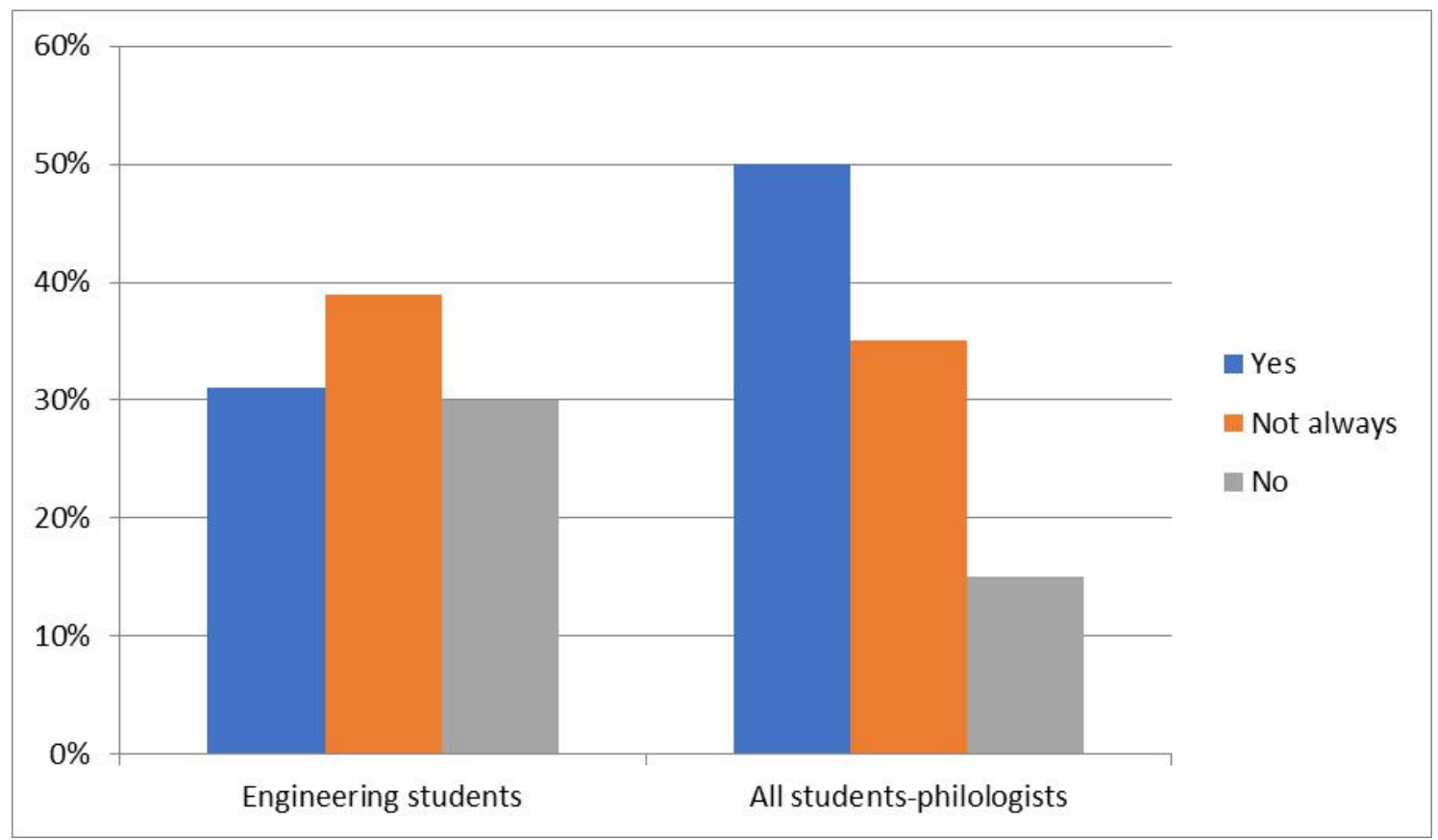

Figure 2. Distribution of respondents' answers to test question 1 
Table 5. Time spent on the Internet.

\begin{tabular}{|c|c|c|c|c|c|c|c|}
\hline \multirow[b]{2}{*}{$\begin{array}{l}\text { Question } \\
\text { numbers }\end{array}$} & \multirow[b]{2}{*}{ Answer option } & \multicolumn{4}{|c|}{ Engineering students } & \multicolumn{2}{|c|}{ Students-philologists } \\
\hline & & $\begin{array}{c}1 \text { year } \\
\text { (42 students) }\end{array}$ & $\begin{array}{c}2 \text { year } \\
\text { (30 students) }\end{array}$ & $\begin{array}{c}3 \text { year } \\
\text { (36 students) }\end{array}$ & $\begin{array}{c}4 \text { year } \\
\text { (29 students) }\end{array}$ & $\begin{array}{c}1 \text { year } \\
\text { (24 students) }\end{array}$ & $\begin{array}{c}1 \text { year } \\
\text { (10 foreign } \\
\text { students) }\end{array}$ \\
\hline \multirow{8}{*}{11} & 1 hour & 4 & 1 & 0 & 3 & 2 & 2 \\
\hline & 2 hours & 4 & 1 & 2 & 6 & 1 & 3 \\
\hline & 3 hours & 8 & 5 & 5 & 8 & 5 & 3 \\
\hline & 4 hours & 11 & 8 & 4 & 6 & 4 & 1 \\
\hline & 5 hours & 7 & 5 & 10 & 2 & 5 & 0 \\
\hline & 6 hours & 3 & 6 & 12 & 1 & 3 & 1 \\
\hline & 7 hours & 2 & 0 & 1 & 1 & 1 & 0 \\
\hline & $\begin{array}{c}8 \text { hours and } \\
\text { more }\end{array}$ & 3 & 4 & 2 & 2 & 3 & 0 \\
\hline \multirow{4}{*}{12} & Daytime & 20 & 6 & 13 & 8 & 10 & 2 \\
\hline & Early evening & 6 & 10 & 9 & 8 & 1 & 6 \\
\hline & Before 12 p.m. & 15 & 13 & 13 & 11 & 9 & 1 \\
\hline & After 12 p.m. & 1 & 1 & 1 & 2 & 4 & 1 \\
\hline
\end{tabular}

Table 6. Grouped results for test question 11.

\begin{tabular}{|c|c|c|c|c|c|c|}
\hline \multirow{2}{*}{ Answer options } & \multicolumn{3}{|c|}{ Engineering undergraduates } & \multicolumn{2}{c|}{ Philological undergraduates } \\
\cline { 2 - 7 } & $\begin{array}{c}\text { 1 year } \\
(42 \text { students })\end{array}$ & $\begin{array}{c}2 \text { year } \\
(30 \text { students })\end{array}$ & $\begin{array}{c}3 \text { year } \\
(36 \text { students })\end{array}$ & $\begin{array}{c}4 \text { year } \\
(29 \text { students })\end{array}$ & $\begin{array}{c}1 \text { year } \\
(24 \text { students })\end{array}$ & $\begin{array}{c}1 \text { year } \\
(10 \text { foreign } \\
\text { students })\end{array}$ \\
\hline 1-2 hours & $8(19 \%)$ & $2(7 \%)$ & $2(6 \%)$ & $9(31 \%)$ & $3(13 \%)$ & $5(50 \%)$ \\
\hline $3-4$ hours & $19(45 \%)$ & $13(43 \%)$ & $9(25 \%)$ & $14(49 \%)$ & $9(38 \%)$ & $4(40 \%)$ \\
\hline 5-6 hours & $10(24 \%)$ & $11(37 \%)$ & $22(61 \%)$ & $3(10 \%)$ & $8(32 \%)$ & $1(10 \%)$ \\
\hline 7 hours or more & $5(12 \%)$ & $4(13 \%)$ & $3(8 \%)$ & $3(10 \%)$ & $4(17 \%)$ & $0(0 \%)$ \\
\hline
\end{tabular}

Answers to question 12 show that, generally, students are online either at daytime or late in the evening. Our assumption that many students surf the Internet long after midnight has not been confirmed.

The most typical answers to question 11 are from three to six hours, therefore, for simplifying the analysis, we have enlarged (doubled) the time interval spent on surfing the network (Table 6).

We did not set a task to find out the reasons for the disparity in the answers given by the students of different courses, therefore we have combined the engineering students into one category (Fig. 3).

Table 6 and the bar chart (Fig. 3) show that on average, the time spent by the students on the Internet amounts to about 4 hours a day, which is quite acceptable. However, some students are online more than 7 hours a day, the girls-philologists being greater in number. The foreign students somewhat fall out of the overall picture: most of them are online for 1-2 hours, they almost do not "surf" the network for 5-6 hours or more. Unlike the majority of the respondents, they are online mainly in the early evening. It can be explained by the cluster character of foreign students' stay in this country - especially of the freshmen. In addition, it is necessary to take into account the difference in national mentality, which greatly affects the norms of behavior as well as the attitude to the Internet. Nevertheless, we believe the general results merely confirm the same distribution of time spent by students on the network.

Now let us consider the data obtained with the help of the questionnaire (Table 2). The initial processing results of the data obtained with the help of the questionnaire are given in Table 7. 


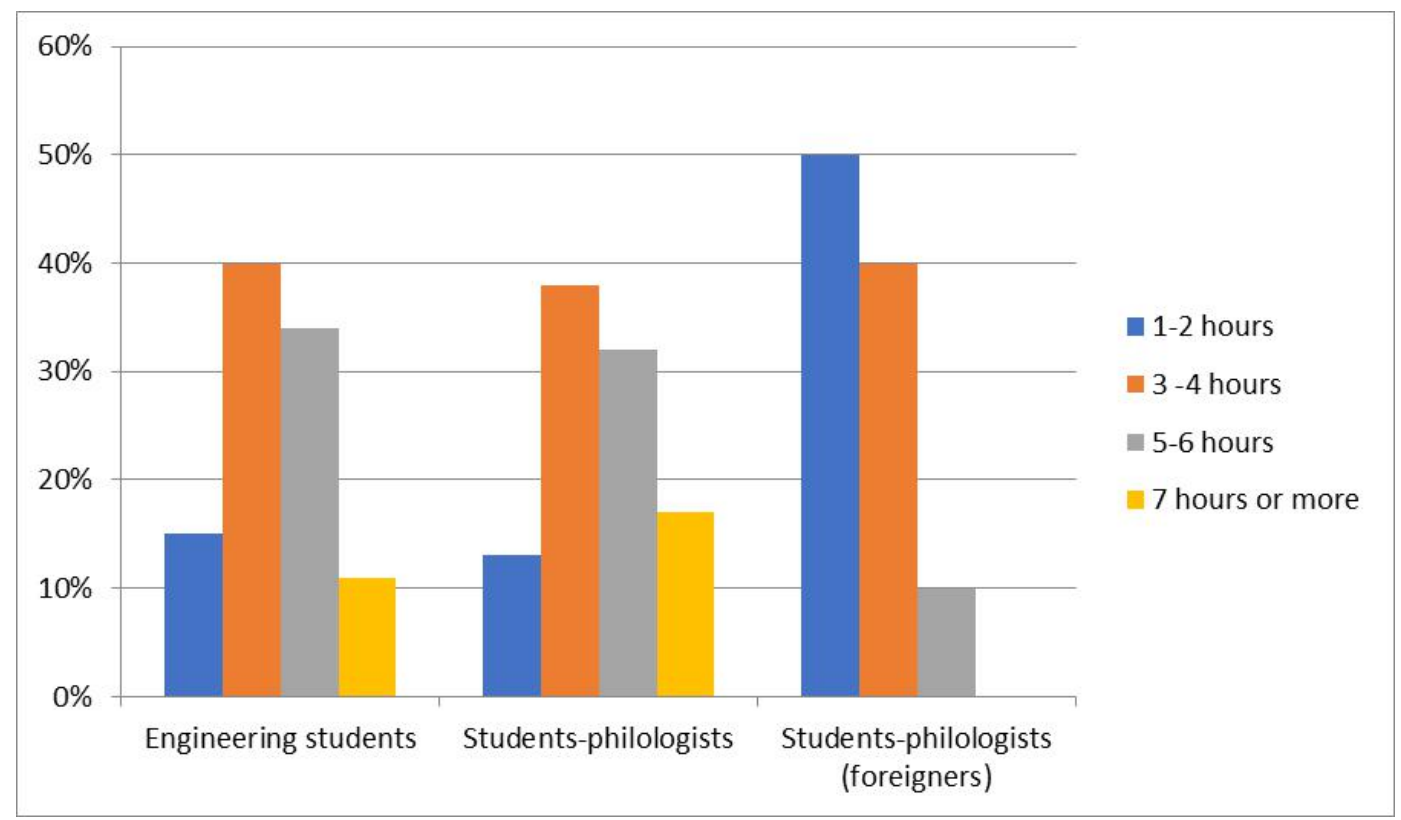

Figure 3. Distribution of respondents' answers according to the time spent on the Internet (question 11).

Table 7. Number of choices in the presented pair of activities engaged by students on the network

\begin{tabular}{|c|c|c|c|}
\hline \multirow[b]{2}{*}{ Pairs of online activities } & \multirow{2}{*}{$\begin{array}{l}\text { Engineering students } \\
1-4 \text { years (137 students) }\end{array}$} & \multicolumn{2}{|c|}{ Students-philologists } \\
\hline & & $\begin{array}{c}1 \text { year } \\
\text { (24 students) }\end{array}$ & $\begin{array}{c}1 \text { year } \\
\text { (10 foreign students) }\end{array}$ \\
\hline 1 / 2 (Studies / "Browsing") & $81 / 56$ & $11 / 13$ & $9 / 1$ \\
\hline $1 / 3$ (Studies / Communication) & $55 / 82$ & $11 / 13$ & $6 / 4$ \\
\hline 1 / 4 (Studies / Hobby) & $50 / 87$ & $3 / 21$ & $4 / 6$ \\
\hline 1 / 5 (Studies / Games) & $94 / 43$ & $22 / 2$ & $10 / 0$ \\
\hline 1 / 6 (Studies / News) & $86 / 51$ & $8 / 16$ & $5 / 5$ \\
\hline 2 / 3 ("Browsing" / Communication) & $56 / 81$ & $12 / 12$ & $3 / 7$ \\
\hline 2 / 4 ("Browsing" / Hobby) & $39 / 93$ & $6 / 18$ & $3 / 7$ \\
\hline 2 / 5 ("Browsing" / Games) & $100 / 37$ & $24 / 0$ & $7 / 3$ \\
\hline 2 / 6 ("Browsing" / News) & $75 / 62$ & $14 / 10$ & $2 / 8$ \\
\hline 3 / 4 (Communication / Hobby) & $76 / 61$ & $7 / 17$ & $5 / 5$ \\
\hline 3 / 5 (Communication / Games) & $117 / 20$ & $22 / 2$ & $10 / 0$ \\
\hline 3 / 6 (Communication /News) & $110 / 27$ & $17 / 7$ & $5 / 5$ \\
\hline 4 / 5 (Hobby / Games) & $114 / 23$ & $24 / 0$ & $10 / 0$ \\
\hline 4 / 6 (Hobby / News) & $116 / 21$ & $22 / 2$ & $3 / 7$ \\
\hline 5 / 6 (Games / News) & $57 / 80$ & $3 / 21$ & $0 / 10$ \\
\hline
\end{tabular}

Further, the number of choices (preferences) for respondents for each of the six activities was calculated. So, for the "Study" type of activity we have: $81+55+50+94+86=366$. The average value per respondent is $366 / 137=2.67$. The ranking for each of the six activities per respondent is shown in Table. 8. 
Table 8. Values of ranking for activities on the network

\begin{tabular}{|c|c|c|c|}
\hline \multirow{2}{*}{ Type of online activity } & \multirow{2}{*}{$\begin{array}{c}\text { Engineering students } \\
\text { 1-4 years (137 students) }\end{array}$} & $\begin{array}{c}\text { Students-philologists } \\
\text { (24 students) }\end{array}$ & $\begin{array}{c}1 \text { year } \\
\text { (10 foreign students) }\end{array}$ \\
\cline { 3 - 4 } & 2.67 & 2.29 & 3.4 \\
\hline Studies & 2.38 & 3.67 & 1.6 \\
\hline "Browsing" & 3.40 & 2.96 & 3.1 \\
\hline Communication & 3.22 & 4.25 & 0.3 \\
\hline Hobby & 1.31 & 0.29 & 3.5 \\
\hline Games & 1.91 & 2.33 & 3.1 \\
\hline
\end{tabular}

The differences in the engineering students' answers depending on the study years are presented in Table 9.

Table 9. Ranking for types of activity on the network for the engineering students depending on study years.

\begin{tabular}{|l|c|c|c|c|}
\hline \multirow{2}{*}{ Type of online activity } & \multicolumn{4}{|c|}{ Engineering students } \\
\cline { 2 - 5 } & 1 year & 2 year & 3 year & 4 year \\
\hline Studies & 2.62 & 2.73 & 2.11 & 3.38 \\
\hline "Browsing" & 2.71 & 2.43 & 2.36 & 1.90 \\
\hline Communication & 3.48 & 3.5 & 3.61 & 2.93 \\
\hline Hobby & 3.29 & 3.23 & 3.61 & 3.66 \\
\hline Games & 1.43 & 0.67 & 1.72 & 1.31 \\
\hline News & 1.62 & 2.1 & 1.58 & 1.83 \\
\hline
\end{tabular}

When analyzing Table 8 , one should take into account, with equal consideration given to all types of online activities, that their ranking is close to 2.5 . It is with regret that we must note the students spend as much time on their studies, their top priority, using their computers as they do on each of the following three activities: communication with friends, hobbies, and surfing the network without any preliminary purpose. News and games are of less interest to the students. One cannot belittle the merits of hobbies as they are a good way to develop human creative thinking and potential. But it is obvious the time spent on aimless and uncontrollable Web surfing should be reduced.

The material of the research presented above shows a general picture characteristic of all categories of the respondents who participated in the survey. However, there are some peculiarities revealed. The foreign students spend much more time on studies than the other respondents (3.4), avoid "browsing" (1.6), are interested in world news (3.5). The domestic students-philologists, mainly girls, like to engage in hobbies (4.25) and unplanned surfing the network (3.67). Engineering students prefer online communication (3.40), in contrast to the students-philologists, partly due to the fact that face-to-face communication causes some difficulties for them. In terms of time spent, "Hobbies" come second, "Studies" come next. When analyzing the results of the survey for different courses (table 9), a certain failure in the attitude to learning among the third-year students and some rise in it of fourth-year students were revealed.

\section{Conclusions}

We believe that excessive passion for secondary activity with the use of ICT, which sometimes turns into Internet addiction, is not a particular phenomenon but a major social problem manifested primarily in the substitution of live communication by virtual one resulting in inevitable impoverishment of social skills, antisocial behavior, and for students - in the decline in the quality of their education.

As it was mentioned above, the engineering students may lack speech and written literacy, experience some difficulties in face-to-face interaction (Gorbunov et al. 2019). Immersed in the virtual world, young people communicate using the language of social networks, which is far from observing literary norms. Besides, due to its specificity the language attempts to economize language means, ignores rules of punctuation and spelling. Adopted from the virtual world and transferred into our real life, this youth slang widely spreads and starts to put serious pressure not only on speech and the generally accepted norms of the language, but on manners, style of behavior of young people and, as a result, their way of thinking as well. It is a serious problem which needs to be solved, otherwise one cannot be confident about future.

For the contingent of the respondents in question, the reasons for a certain Internet addiction are different. However, it seems that the phenomenon of psychological self-defence of the individual, the desire to get away from the problems that are difficult to solve are manifested. The insufficient level of general culture, discipline, strong-willed qualities, low need for knowledge, the lack of a meaningful, professionally-oriented goal of education determine the negative impact of ICT on a significant part of students acquiring engineering specialities. It is very important to improve students' self-esteem through their achievements in life, firstly, in studies. A system of education for students of engineering undergraduate must be organized so as to create all necessary conditions for acquiring knowledge, formation of skills and competences approved by the society. Attention should be paid to the 
quality of training and learning in a professionally relevant area, the development of the ability to predict the outcomes of one's activities. At the same time, one should take into account that at present a majority of teachers at Russian regional universities have neither motivation to improve the situation in this area, nor means to change it for better.

\section{Ethical Approval}

This article does not contain any studies with human participants or animals performed by any of the authors.

\section{Compliance with Ethical Standards}

\section{Conflict of Interest}

The authors declare that they have no conflict of interest.

\section{Informed Consent}

The students' survey was anonymous.

\section{REFERENCES}

[1] Abeysekera, L., \& Dawson, P. (2015). Motivation and cognitive load in the flipped classroom: Definition, rationale and a call for research. Higher Education Research \& Development, 34(1), 1-14.https://doi.org/10.1080/07294360.2014.934336.

[2] Al-araibi, A.A.M., Naz'ri bin Mahrin, M., Yusoff, R.C.M. \& Chuprat, S.B. (2019). A model for technological aspect of e-learning readiness in higher education. Educ. Inf. Technol. 24 1395-1431.https://doi.org/10.1007/s10639-018-9837-9.

[3] Alemu, B.M. (2015). Integrating ICT into teaching-learning practices: Promise, challenges and future directions of higher educational institutes. Universal Journal of Educational Research, 3(3), 170-189.https://doi.org/10.13189/ujer.2015.030303.

[4] Andreev, V.V., Gibadulin, R.Ya., Prodanov, G. \& Zhdanov, R.I. (2017). Russian Institute for Advanced Study as a new form of training of highly trained teaching staff. Integration of Education, 21(4), 623-636. (In Russ.).https://doi.org/10.15507/1991-9468.089.021.20170 4.623-636.

[5] Barrera J., Saura-Mas S. \& Blanco A. (2018). Transperformative education: Toward a new educational paradigm based on transdisciplinarity and artistic performativity. World Futures, Latest Articles. https://doi.org/10.1080/02604027.2018.1463761.

[6] Cruzado, I. \& Román, E.M. (2015). Inverted classroom and its influence on students' attitudes across learning styles. Transportation Research Record, 2480, 38-44.https://doi.org/10.3141/2480-05.

[7] Fernáández Batanero, J.M., Reyes Rebollo, M.M. \& Montenegro Rueda, M. (2019). Impact of ICT on students with high abilities. Bibliographic review (2008-2018). Computers and Education, 137, 48-58.https://doi.org/10.1016/j.compedu.2019.04.007.

[8] Florjančič, V. (2015) The Information Society, a Challenge for Business Students? In: Uden, L., Liberona, D., Welzer, T. (eds) Learning Technology for Education in Cloud. LTEC 2015. Communications in Computer and Information Science, 533, 177-187. Springer, Cham.https://doi.org/10.1007/978-3-319-22629-3_14.

[9] Florjančič, V. (2019). Facing a Digital Challenge at a Traditional University. Communications in Computer and Information Science, 1011, 279-291.https://doi.org/10.1007/978-3-030-20798-4_24.

[10] Giannakopoulos, A. \& Eybers, S. (2015). The Adoption of Mobile Technologies in a Higher Education Institution: A Mixed Methods Study. In: Brown, T., van der Merwe, H. (eds) The Mobile Learning Voyage - From Small Ripples to Massive Open Waters. mLearn 2015. Communications in Computer and Information Science, 560, 283-299. Springer,

Cham. https://doi.org/10.1007/978-3-319-25684-9_21.

[11] Goedhart, N.S., Blignaut-van Westrhenen, N., Moser, C. \& Zweekhorst, M.B.M. (2019). The flipped classroom: supporting a diverse group of students in their learning. Learning Environments Research, 22 (2), 297-310. https://doi.org/10.1007/s10984-019-09281-2.

[12] Gorbunov, V.I., Evdokimova, O.K. \& Lyapaeva, L.V. (2016). Intelligence of regional technical institute students: posing the problem, means of evaluation, trial results. Yakovlev Chuvash State Pedagogical University Bulletin, 1, 82-90. (In Russ.). Retrieved athttps://elibrary.ru/item.asp?id=25792028. Accessed 14 Sep 2019.

[13] Gorbunov, V.I., Evdokimova, O.K., Rimondi, G. \& Andreev, V.V. (2019). Acquiring transdisciplinary knowledge by engineering students of Russian universities. Science for Education Today, 1. 172-187. (In Russ.).http://dx.doi.org/10.15293/2658-6762.1901.11.

[14] Hatlevik, O.E. \& Christophersen, K. (2013). Digital competence at the beginning of upper secondary school: Identifying factors explaining digital inclusion. Computers \& Education, 63, 240-247.https://doi.org/10.1016/j.compedu.2012.11.015.

[15] Hernandez-de-Menendez, M. \& Morales-Menendez, R. (2019). Technological innovations and practices in engineering education: a review. Int. J. Interact. Des. Manuf., $\quad 13 \quad$ (2), $113-728$. https://doi.org/10.1007/s12008-019-00550-1.

[16] Hohlfeld, T.N., Ritzhaupt, A.D. \& Barron, A.E. (2013). Are gender differences in perceived and demonstrated technology literacy significant? It depends on the model. Educational Technology Research \& Development, 61, 639-663. https://doi.org/10.1007/s11423-013-9304-7.

[17] Hollman, A.K., Hollman, T.J., Shimerdla, F., Bice, M.R. \& 
Adkins, M. (2019). Information technology pathways in education: Interventions with middle school students. Computers \& Education, 135, 49-60.https://doi.org/10.1016/j.compedu.2019.02.019.

[18] List, A. (2019). Defining digital literacy development: An examination of pre-service teachers' beliefs. Computers and Education, 138, 146-158.https://doi.org/10.1016/j.compedu.2019.03.009.

[19] Luisa Sevillano-García, M. \& Vázquez-Cano, E. (2015). The impact of digital mobile devices in higher education. Educational Technology and Society, 18 (1), 106-118. Retrieved athttps://pdfs.semanticscholar.org/ae1c/931d52bf03c50cc5 21fda42454d1 cda4acf7.pdf? ga=2.12025776.505818773.1 562937938-1284382026.1562937938. Accessed 14 Sep 2019.

[20] Martins, J., Branco, F., Gonçalves, R., Au-Yong-Oliveira, M., Oliveira, T., Naranjo-Zolotov, M. \& Cruz-Jesus, F. (2019). Assessing the success behind the use of education management information systems in higher education. Telematics and Informatics, 38, 182-193. https://doi.org/10.1016/j.tele.2018.10.001.

[21] O'Flaherty, J. \& Phillips, C. (2015). The use of flipped classrooms in higher education: A scoping review. The Internet and Higher Education, 25, 85-95.http://dx.doi.org/10.1016/j.iheduc.2015.02.002.

[22] Pinto, M., Fernández-Pascual, R., Caballero-Mariscal, D., Sales, D., Guerrero, D. \& Uribe, A. (2019). Scientific production on mobile information literacy in higher education: a bibliometric analysis (2006-2017). Scientometrics, $\quad 120$ 57-85.https://doi.org/10.1007/s11192-019-03115-x.

[23] Prevalla, B. \& Uzunboylu, H. (2019). Flipped Learning in Engineering Education. TEM Journal, 8 (2), 656-661. https://doi.org/10.18421/TEM82-46.

[24] Priyaadharshini, M. \& Vinayaga Sundaram, B. (2017). Lifelong learning: Analyzing behavioral models using cloud based flipped classroom. Journal of Computational and Theoretical Nanoscience, 14 (12), 5770-5779. https://doi.org/10.1166/jctn.2017.7011.

[25] Rajabion, L., Wakil, K., Badfar, A., Mojtabavi Naeini, S. \& Zareie, B. (2019). A new model for assessing the impact of ICT and digital knowledge on students' thoughts and beliefs. Journal of Engineering, Design and Technology. https://doi.org/10.1108/JEDT-01-2019-0008.

[26] Rizvi, S., Rienties, B. \& Khoja, Sh.A. (2019). The role of demographics in online learning; A decision tree based approach. Computers \& Education, 137, 32-47.https://doi.org/10.1016/j.compedu.2019.04.001.

[27] Scherer, R. \& Siddiq, F. (2019). The relation between students' socioeconomic status and ICT literacy: Findings from a meta-analysis. Computers and Education, 138, 13-32. https://doi.org/10.1016/j.compedu.2019.04.011.

[28] Siddiq, F. \& Scherer, R. (2019). Is there a gender gap? A meta-analysis of the gender differences in students' ICT literacy. Educational Research Review, 27, 205-217. https://doi.org/10.1016/j.edurev.2019.03.007.

[29] Smol, M. \& Kulczycka, J. (2019). Towards innovations development in the European raw material sector by evolution of the knowledge triangle. Resources Policy, 62, 453-462. https://doi.org/10.1016/j.resourpol.2019.04.006.

[30] Suryawanshi, K. (2019). Green Information and Communication Technology Techniques in Higher Technical Education Institutions for Future Sustainability. In: Balas, V., Sharma, N., Chakrabarti, A. (eds) Data Management, Analytics and Innovation. Advances in Intelligent Systems and Computing, 839, 35-43. Springer, Singapore. https://doi.org/10.1007/978-981-13-1274-8_3.

[31] Tejedor, G., Segalàs, J. \& Rosas-Casals, M. (2018). Transdisciplinarity in higher education for sustainability: How discourses are approached in engineering education. Journal of Cleaner Production, 175, 29-37.https://doi.org/10.1016/j.jclepro.2017.11.085.

[32] Tokareva, E.A., Smirnova, Y.V. \& Orchakova, L.G. (2019). Innovation and communication technologies: Analysis of the effectiveness of their use and implementation in higher education. Educ. Inf. Technol.https://doi.org/10.1007/s10639-019-09922-2.

[33] Valencia-Arias, A., Chalela-Naffah, S. \& Bermúdez-Hernández, J. (2019). A proposed model of e-learning tools acceptance among university students in developing countries. Educ. Inf. Technol., 24 (2), 1057-1071. https://doi.org/10.1007/s10639-018-9815-2.

[34] Young, K.S. Caught in the Net: How to Recognize the Signs of Internet Addiction and a Winning Strategy for Recovery. New York, John Wiley \& Sons, Inc. 1998. 256 p.

[35] Young, K.S. \& Brand, M. (2017). Merging Theoretical Models and Therapy Approaches in the Context of Internet Gaming Disorder: A Personal Perspective. Front. Psychol., 8, Article 1853. https://doi.org/10.3389/fpsyg.2017.01853.

[36] Zeidmane, A. (2019). ICT in life of students at the Latvia university of Life sciences and Technologies. Engineering for Rural Development, 18, 1927-1932. https://doi.org/10.22616/ERDev2019.18.N425. 